\title{
Analysis of the level of selected parameters of inflammation, circulating immune complexes, and related indicators (neutrophil/ lymphocyte, platelet/lymphocyte, CRP/CIC) in patients with obstructive diseases
}

\author{
MARTA PILACZYŃSKA-CEMEL ${ }^{1}$, RYSZARD GOEDA ${ }^{2}$, ANITA DAZBROWSKA \\ GRZEGORZ PRZYBYLSKI ${ }^{1}$
}

${ }^{1}$ Department of Lung Diseases, Cancer and Tuberculosis, Ludwik Rydygier Collegium Medicum in Bydgoszcz, Nicolaus Copernicus University in Torun, Bydgoszcz, Poland

${ }^{2}$ Department of Immunobiology, Institute of Experimental Biology, Kazimierz Wielki University in Bydgoszcz, Bydgoszcz, Poland ${ }^{3}$ Department of Didactics, Ludwik Rydygier Collegium Medicum in Bydgoszcz, Nicolaus Copernicus University in Torun, Bydgoszcz, Poland

\begin{abstract}
Introduction: Chronic obstructive pulmonary disease (COPD) is an inflammatory disorder of the airways. An important element of COPD assessment is the evaluation of immune mechanisms involved in non-specific and specific response to ongoing inflammation.

Aim of the study: To evaluate the level of selected inflammatory and immunological parameters in patients with COPD, including $C$-reactive protein $(C R P)$ and circulating immune complexes $(C I C)$, as well as $C R P / C I C$ index.

Material and methods: The study group consisted of 49 patients with obstructive pulmonary diseases (COPD, asthma, and asthma-COPD overlap syndrome) hospitalised in the Department of Pulmonary Diseases, Kuyavian-Pomeranian Pulmonology Centre in Bydgoszcz. Patients with COPD were divided into two subgroups, taking into account the severity of the disease according to the Global Initiative for Chronic Obstructive Lung Disease (GOLD; stages B and D). The control group consisted of 30 healthy persons. Levels of CIC were determined by the method of Hasková, and the concentration of CRP in serum by the standard immunoturbidimetric method.

Results: The median values of examined parameters (neutrophils, lymphocytes, platelets, neutrophil/lymphocyte ratio - NLR, platelet/lymphocyte ratio-PLR, CRP, CIC, and CRP/CIC index) were significantly higher among patients with obstructive diseases than in the control group. A tendency towards higher lymphocyte count, CRP, and CRP/CIC index in COPD stage D, compared to stage B, was observed.

Conclusions: Based on our results, we suggest that the role of non-specific inflammatory mechanisms may increase in more advanced COPD stages $(D)$, compared to less advanced stages $(B)$.
\end{abstract}

Key words: neutrophil/lymphocyte ratio, platelet/lymphocyte ratio, circulating immune complexes, obstructive diseases.

(Centr Eur J Immunol 2019; 43 (3): 292-298)

\section{Introduction}

Chronic obstructive pulmonary disease (COPD) is an inflammatory disease of the airways caused by inhalation of toxic substances, among others - in cigarette smokers, and in workers of the chemical industry [1]. It is assumed that COPD is associated with a wide range of consequences, in particular systemic inflammation [2].

The intensity of inflammation may be related to the severity of the disease influencing the degree of airway

Correspondence: Marta Pilaczyńska-Cemel, MD, Department of Lung Diseases, Cancer and Tuberculosis, Ludwik Rydygier Collegium Medicum in Bydgoszcz, Nicolaus Copernicus University in Torun, 13 Jagiellońska St., 85-067 Bydgoszcz, Poland, e-mail: mpilaczynska@wp.pl Submitted: 27.11.2018; Accepted: 12.08.2019 
obstruction. The obstruction of the airways is assessed by spirometry, and its intensity is defined as the percentage of predicted value of forced expired volume in one second (FEV1). Nevertheless, FEV1 does not sufficiently represent the complexity of this disease [3].

In spite of intensive multidirectional studies on the pathogenesis and natural course of COPD, optimal assessment of the clinical course of disease in individual patients has not been determined. The state of systemic inflammation in obstructive lung diseases remains unknown.

A number of cytokines involved in the pathogenesis of bronchial asthma and COPD have been described. An important element of the characteristics of COPD is a proper assessment of the immune mechanisms involved in the non-specific and specific response to ongoing inflammation. Elevated levels of circulating immune complexes (CIC) are associated with chronic inflammation, neoplasm, autoimmune disorders, and allergic reaction $[4$, 5], and they may reflect the specific humoral activation of the immune system.

Other indicators of inflammation, characterised by low specificity for aetiological agents, are acute phase proteins, among others - C-reactive protein (CRP). CRP is synthesised in the liver and is an accepted early marker of inflammation [6]. Increased serum CRP is associated with impaired lung function and poor prognosis in COPD patients $[7,8]$.

The numbers and subtypes of white blood cells (WBCs) are also well-known systemic non-specific cellular markers of inflammation. The ratio of neutrophils to lymphocytes (NLR), counted from the total number of blood cells, is an inexpensive, commonly available, general marker of inflammation. The usefulness of NLR has been demonstrated in the risk assessment of cardiovascular diseases, many types of solid tumours, sepsis, and infectious diseases $[1,9,10]$.

The ratio of the absolute number of platelets to the absolute number of lymphocytes, referred to as the PLR, is used to assess not only the humoral response, but also the coagulation process. It is therefore a useful parameter in assessing the overall response to inflammation and neoplasm [11].

Lung diseases (primarily COPD) are the fourth cause of death in Poland [12], so research concerning their pathogenesis, prophylaxis, and treatment is justified.

The aims of the study were:

1. Evaluation of the levels of selected inflammatory parameters in patients with obstructive pulmonary diseases, compared to the healthy population.

2. Evaluation of the predictive value of NLR and PLR in patients with chronic obstructive pulmonary disease.

3. An attempt to investigate the usefulness of CRP/CIC index in the assessment of inflammation in obstructive lung diseases.

\section{Material and methods}

The study group consisted of 49 patients with obstructive lung diseases, hospitalised in the Department of Pulmonary Diseases and Tuberculosis of the KuyavianPomeranian Pulmonology Centre in Bydgoszcz. Thirtyfour patients were diagnosed with COPD, 10 with bronchial asthma, and five with asthma-COPD overlap. Chronic obstructive pulmonary disease was diagnosed on the basis of clinical criteria with confirmation of irreversible obstruction in a functional test based on the GOLD 2016 guidelines [13]. Bronchial asthma was diagnosed on the basis of clinical criteria and confirmation in functional studies of reversible obstruction or its variability based on the GINA 2016 guidelines [14]. Bronchial asthma overlap with COPD was diagnosed in the patients with symptoms of asthma and established bronchial obstruction typical of COPD.

Smokers accounted for $66 \%$ and non-smokers (including those who stopped smoking 20 years ago and more) $-34 \%$ of the examined population.

The examined group of patients with stable COPD were divided into two subgroups, taking into account the severity of the disease according to GOLD. The first subgroup included patients with mild to moderate disease (severity of clinical symptoms in mRC scale, number of exacerbations/hospitalisations, and degree of obstruction in spirometry) - stage B; and a subgroup with moderately severe and severe COPD - stage D [2]. There were no statistically significant differences between COPD, asthma, and asthma-COPD overlap groups concerning the age, sex, and smoking (Table 1).

The control group consisted of 30 healthy persons aged 19 to 69 years. The control group did not differ significantly from the examined group in terms of sex distribution (women accounted for $55 \%$, men $45 \%$ ), place of residence (residence in the city was dominating $-64 \%$ vs. $36 \%$ ), and marital status (married $-78 \%$; divorced $-6 \%$; and unmarried - 16\%).

The analysed material was serum obtained from venous blood. Levels of immunological complexes were determined by the method of Hasková et al. [15]. $0.3 \mathrm{ml}$ of 0.1 molar borate buffer $\mathrm{pH} 8.4$ and $4.05 \mathrm{ml}$ of $4.17 \%$ PEG 6000 solution in the same buffer were added to $0.15 \mathrm{ml}$ of the test serum. The extinction value of the solutions was tested at $450 \mathrm{~nm}$. The reading was carried out after a onehour incubation at room temperature. The reference sample was a mixture of PEG and borate buffer. The concentration of CRP in serum was determined by the standard immunoturbidimetric method. The morphology blood cell counts were determined using a Sysmex XT1800i analyser. White blood cell subpopulations were evaluated using the above apparatus. From the percentage value of neutrophils and lymphocytes and the number of WBC, the absolute numbers of these fractions were calculated. The NLR was cal- 
Table 1. Characteristics of the study group

\begin{tabular}{|c|c|c|c|c|}
\hline Characteristic & COPD & Asthma & Asthma-COPD overlap & $p$ \\
\hline Subjects & 35 & 9 & 5 & \\
\hline Age, years (medians [interquartile range]) & $69.0(66.0-80.0)$ & $66.0(62.0-68.0)$ & $69.0(66.0-67.0)$ & 0.11 \\
\hline Sex, $n$ & & & & 0.39 \\
\hline male & $20(57.1 \%)$ & $3(33.3 \%)$ & $2(40.0 \%)$ & \\
\hline female & 15 & 6 & 3 & \\
\hline Smoking, $n$ & & & & 0.31 \\
\hline current smoker & $25(71.4 \%)$ & $4(44.4 \%)$ & $3(60.0 \%)$ & \\
\hline ex-smoker & 10 & 5 & 2 & \\
\hline Stadium of COPD, $n$ & & & & 1.00 \\
\hline $\mathrm{B}$ & $21(60.0 \%)$ & & $3(60.0 \%)$ & \\
\hline D & 14 & & 2 & \\
\hline
\end{tabular}

COPD - chronic obstructive pulmonary disease

Table 2. The influence of demographic factors on the level of absolute neutrophils

\begin{tabular}{|c|c|c|}
\hline Characteristic & $\begin{array}{c}\text { Absolute } \\
\text { neutrophils } \\
\left(\times 10^{3} / \mu \mathrm{l}\right)\end{array}$ & $p$ \\
\hline Age & & 0.27 \\
\hline up to 70 years (inclusive) $(n=31)$ & $7.10(4.90,3.42)$ & \\
\hline over 70 years $(n=18)$ & $8.10(6.10,10.10)$ & \\
\hline Gender & & 0.05 \\
\hline female $(n=24)$ & $6.30(4.70,8.40)$ & \\
\hline male $(n=25)$ & $8.00(6.70,10.30)$ & \\
\hline Smoking & & 0.58 \\
\hline smokers $(n=32)$ & $7.10(5.20,8.60)$ & \\
\hline non-smokers $(n=17)$ & $8.10(5.60,10.20)$ & \\
\hline Diagnosis & & 0.07 \\
\hline bronchial asthma $(n=10)$ & $5.60(4.60,8.10)$ & \\
\hline $\begin{array}{l}\text { bronchial asthma-COPD + COPD } \\
(n=39)\end{array}$ & $7.90(5.60,10.10)$ & \\
\hline GOLD severity & & 0.40 \\
\hline $\mathrm{D}(n=16)$ & $7.30(5.05,8.35)$ & \\
\hline $\mathrm{B}(n=23)$ & $8.00(5.60,10.20)$ & \\
\hline
\end{tabular}

culated as the ratio of the absolute neutrophil count to the absolute lymphocyte number, and the PLR as the ratio of absolute platelet count to absolute lymphocyte number.

The applied statistical methods took into account the fact that the values of CRP, CIC, and age variables turned out to be significantly different from the normal distribution. Non-parametric analyses were used in the study, and
Table 3. The influence of demographic factors on the level of absolute lymphocytes

\begin{tabular}{|c|c|c|}
\hline Characteristic & $\begin{array}{c}\text { Absolute } \\
\text { lymphocytes } \\
\left(\times 10^{3} / \mu \mathrm{l}\right)\end{array}$ & $p$ \\
\hline Age & & 0.81 \\
\hline up to 70 years (inclusive) $(n=31)$ & $1.30(0.90,1.80)$ & \\
\hline over 70 years $(n=18)$ & $1.00(0.70,2.10)$ & \\
\hline Gender & & 0.88 \\
\hline female $(n=24)$ & $1.30(0.85,1.81)$ & \\
\hline male $(n=25)$ & $1.30(0.80,1.90)$ & \\
\hline Smoking & & 0.30 \\
\hline smokers $(n=32)$ & $1.35(1.00,1.90)$ & \\
\hline non-smokers $(n=17)$ & $0.90(0.80,1.80)$ & \\
\hline Diagnosis & & 0.53 \\
\hline bronchial asthma $(n=10)$ & $1.25(0.90,1.70)$ & \\
\hline $\begin{array}{l}\text { bronchial asthma-COPD + COPD } \\
(n=39)\end{array}$ & $1.30(0.80,2.00)$ & \\
\hline GOLD & & 0.25 \\
\hline $\mathrm{D}(n=16)$ & $1.55(1.25,1.95)$ & \\
\hline $\mathrm{B}(n=23)$ & $1.20(0.70,1.90)$ & \\
\hline
\end{tabular}

$\overline{C O P D-c h r o n i c ~ o b s t r u c t i v e ~ p u l m o n a r y ~ d i s e a s e, ~ G O L D ~-~ G l o b a l ~ I n i t i a t i v e ~}$ for Chronic Obstructive Lung Disease

the values of quartiles are given in the text (medians with a quartile compartment designated by the lower and upper quartiles). The Mann-Whitney test was used to compare the medians in the independent groups. Correlations between variables were examined using the Spearman's rank correlation coefficient. For categorical variables, the $\chi^{2}$ independence test and the test comparing the structure index 
Table 4. The influence of demographic factors on the level of neutrophil/lymphocyte ratio

\begin{tabular}{|c|c|c|}
\hline Characteristic & $\begin{array}{l}\text { Neutrophil/ } \\
\text { lymphocyte }\end{array}$ & $p$ \\
\hline \multicolumn{2}{|l|}{ Age } & \multirow[t]{3}{*}{0.58} \\
\hline up to 70 years (inclusive) $(n=31)$ & $4.80(3.50,6.60)$ & \\
\hline over 70 years $(n=18)$ & $6.65(3.00,11.80)$ & \\
\hline \multicolumn{2}{|l|}{ Gender } & \multirow[t]{3}{*}{0.46} \\
\hline female $(n=24)$ & $4.70(2.90,11.15)$ & \\
\hline male $(n=25)$ & $6.10(3.80,9.80)$ & \\
\hline \multicolumn{2}{|l|}{ Smoking } & \multirow[t]{3}{*}{0.39} \\
\hline smokers $(n=32)$ & $5.00(2.95,8.20)$ & \\
\hline non-smokers $(n=17)$ & $5.00(4.00,11.80)$ & \\
\hline \multicolumn{2}{|l|}{ Diagnosis } & \multirow[t]{3}{*}{0.59} \\
\hline bronchial asthma $(n=10)$ & $4.75(3.00,6.40)$ & \\
\hline $\begin{array}{l}\text { bronchial asthma-COPD + COPD } \\
(n=39)\end{array}$ & $5.40(3.10,11.70)$ & \\
\hline \multicolumn{2}{|l|}{ GOLD } & \multirow[t]{3}{*}{0.28} \\
\hline $\mathrm{D}(n=16)$ & $4.75(3.05,6.50)$ & \\
\hline $\mathrm{B}(n=23)$ & $5.40(3.10,11.80)$ & \\
\hline
\end{tabular}

for the sample with the known structure index for the population were used. The results were considered statistically significant for the probability value $p<0.05$.

The tests were approved by the Bioethical Commission at the Nicolaus Copernicus University in Torun, Collegium Medicum in Bydgoszcz, number: KB 3354/2017.

\section{Results}

The study group was divided according to age (up to 70 years and over 70 years), gender, smoking, clinical diagnosis, and the stage of COPD according to GOLD. The results of absolute neutrophils are presented in Table 2, absolute lymphocytes in Table 3, NLR in Table 4, PLR in Table 5, and platelets in Table 6. Median neutrophil values did not depend on age, smoking, diagnosis, and stage of disease according to GOLD. Among men, there was a significant tendency towards higher values of neutrophilic level. Median lymphocytes, NLR, and PLR did not differ significantly among the studied demographic factors. When analysing platelet values, there was a statistically significant trend towards higher platelet counts among women (this is not true - Table 6 shows higher platelet values in men). Platelet values did not differ among the other groups.

The examined parameters (neutrophils, lymphocytes, platelets, NLR, PLR, CRP, CIC, and CRP/CIC index) were
Table 5. The influence of demographic factors on the level of platelet/lymphocyte ratio

\begin{tabular}{|c|c|c|}
\hline Characteristic & $\begin{array}{c}\text { Platelet/ } \\
\text { lymphocyte }\end{array}$ & $p$ \\
\hline Age & & 0.63 \\
\hline up to 70 years (inclusive) $(n=31)$ & $17.6(11.50,26.40)$ & \\
\hline over 70 years $(n=18)$ & $25.00(11.10,43.10)$ & \\
\hline Gender & & 0.32 \\
\hline female $(n=24)$ & $17.15(11.40,25.25)$ & \\
\hline male $(n=25)$ & $20.40(12.20,38.20)$ & \\
\hline Smoking & & 0.65 \\
\hline smokers $(n=32)$ & $18.60(11.50,28.30)$ & \\
\hline non-smokers $(n=17)$ & $19.80(11.20,47.80)$ & \\
\hline Diagnosis & & 0.23 \\
\hline bronchial asthma $(n=10)$ & $13.65(10.30,24.10)$ & \\
\hline $\begin{array}{l}\text { bronchial asthma-COPD + COPD } \\
(n=39)\end{array}$ & $20.40(12.20,30.50)$ & \\
\hline GOLD & & 0.23 \\
\hline $\mathrm{D}(n=16)$ & $17.65(12.20, .85)$ & \\
\hline $\mathrm{B}(n=23)$ & $24.80(11.50,47.80)$ & \\
\hline
\end{tabular}

COPD - chronic obstructive pulmonary disease, GOLD - Global Initiative for Chronic Obstructive Lung Disease

Table 6. The influence of demographic factors on the level of absolute platelets

\begin{tabular}{|c|c|c|}
\hline Characteristic & $\begin{array}{l}\text { Absolute platelets } \\
\qquad\left(\times 10^{3} / \mu \mathrm{l}\right)\end{array}$ & $p$ \\
\hline Age & & 0.83 \\
\hline up to 70 years (inclusive) $(n=31)$ & $237.6(178.6,289.2)$ & \\
\hline over 70 years $(n=18)$ & $220.3(180.9,355.2)$ & \\
\hline Gender & & 0.05 \\
\hline female $(n=24)$ & $202.5(163.3,273.7)$ & \\
\hline male $(n=25)$ & $254.8(198.0,421.6)$ & \\
\hline Smoking & & 0.70 \\
\hline smokers $(n=32)$ & $223.2(179.8,279.9)$ & \\
\hline non-smokers $(n=17)$ & $239.0(198.0,355.2)$ & \\
\hline Diagnosis & & 0.11 \\
\hline bronchial asthma $(n=10)$ & $195.9(149.5,275.0)$ & \\
\hline $\begin{array}{l}\text { bronchial asthma-COPD + COPD } \\
(n=39)\end{array}$ & $244.0(189.0,364.0)$ & \\
\hline GOLD & & 0.64 \\
\hline $\mathrm{D}(n=16)$ & $209.4(182.4,330.6)$ & \\
\hline $\mathrm{B}(n=23)$ & $244.0(180.9,355.2)$ & \\
\hline
\end{tabular}

COPD - chronic obstructive pulmonary disease, GOLD - Global Initiative for Chronic Obstructive Lung Disease 
Table 7. The comparison of selected inflammatory parameters (humoral and cellular) in patients with chronic obstructive pulmonary disease and in the control group

\begin{tabular}{lccc}
\hline Variable & Obstructive diseases $(\boldsymbol{n}=\mathbf{4 9})$ & Control group $(\boldsymbol{n}=\mathbf{3 0})$ & $\boldsymbol{p}$ \\
\hline Absolute neutrophils & $7.90(5.60,10.10)$ & $2.9(2.3,3.8)$ & $<0.001$ \\
\hline Absolute lymphocytes & $1.3(0.8,1.8)$ & $1.9(1.5,2.2)$ & $<0.001$ \\
\hline Absolute platelets & $238.0(181.0,289.0)$ & $119.0(99.0,144.0)$ & $<0.001$ \\
\hline Neutrophil/lymphocyte & $5.0(3.1,10.6)$ & $1.7(1.1,2.0)$ & $<0.001$ \\
\hline Platelet/lymphocyte & $19.6(11.5,30.3)$ & $64.0(55.0,93.0)$ & $<0.001$ \\
\hline CRP & $8.0(2.2,34.0)$ & $0.7(0.2,1.3)$ & $<0.001$ \\
\hline CIC & $0.31(0.26,0.36)$ & $0.14(0.11,0.17)$ & $<0.001$ \\
\hline CRP/CIC & $34.0(7.4,102.4)$ & $6.0(1.0,13.0)$ & $<0.001$ \\
\hline CRP-C-reci
\end{tabular}

CRP-C-reactive protein, CIC-circulating immune complexes

Table 8. The comparison of inflammatory parameters (humoral and cellular) in the two groups in COPD divided by the severity of the disease

\begin{tabular}{lccc}
\hline Variable & Group B COPD $(\boldsymbol{n}=\mathbf{2 3})$ & Group D COPD $(\boldsymbol{n}=\mathbf{1 6})$ & $\boldsymbol{p}$ \\
\hline Absolute neutrophils & $8.0(5.6,10.2)$ & $7.3(5.1,8.4)$ & 0.40 \\
\hline Absolute lymphocytes & $1.2(0.7,1.9)$ & $1.6(1.3,1.9)$ & 0.25 \\
\hline Absolute platelets & $244.0(180.9,355.2)$ & $209.0(182.0,331.0)$ & 0.65 \\
\hline Neutrophil/lymphocyte & $5.40(3.10,11.80)$ & $4.7(3.1,6.5)$ & 0.27 \\
\hline Platelet/lymphocyte & $24.8(11.5,47.8)$ & $17.7(12.2,24.9)$ & 0.23 \\
\hline CRP & $6.9(1.7,26.0)$ & $11.6(3.6,35.0)$ & 0.56 \\
\hline CIC & $0.32(0.26,0.36)$ & $0.32(0.26,0.41)$ & 0.84 \\
\hline CRP/CIC & $27.3(5.8,102.4)$ & $36.1(12.6,56.9)$ & 0.56 \\
\hline COPD-chronic obstructive pulmonary disease, CRP-C-reactive protein, CIC-circulating immune complexes &
\end{tabular}

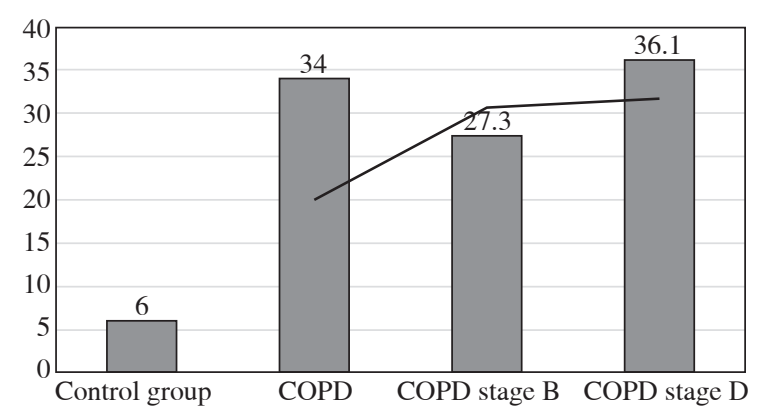

Fig. 1. Median values of CRP/CIC index in the study group and control group

compared in the study and control group (Table 7). It was shown that all results were significantly different. In the study group, the median neutrophils and platelets were found to be significantly higher than in the control group. Consequently, median NLR and PLR were significantly higher. Among people with obstructive diseases, significantly higher median values were found for both CRP and CIC compared to those in the control group.
The studied parameters were analysed in subgroups B and D of COPD patients (Table 8).

The values of the CRP/CIC index were higher in the group of patients with COPD stage D comparing to stage B (Fig. 1). On the other hand, the values of NLR and PLR were slightly lower in COPD stage $\mathrm{D}$, compared to stage B (Fig. 2 and 3). The results in both compared groups did not differ statistically.

\section{Discussion}

Research conducted in recent years suggests the systemic nature of both acute and chronic diseases. Chronic obstructive pulmonary disease, according to current knowledge, belongs to such systemic pathologies. The inflammatory process underlying this disease influences not only the alveoli and the bronchi, but also the respiratory muscles (leading to their atrophy), endothelial cells (increasing the risk of cardiovascular disease), and cartilage-bone tissue (hence the greater tendency of osteoporosis among patients with COPD). There is evidence that systemic effects can significantly modify the activity of local inflammation [16]. 
Looking for the relationship between systemic inflammation and local inflammation in the lungs, we analysed a number of factors. We investigated nonspecific and specific humoral mechanisms, with special respect paid to the role of CRP/CIC index.

The CRP/CIC index in healthy people is a reflection of the dynamic balance between nonspecific and specific humoral response. In our study among patients with obstructive lung diseases, this value exceeded by six-fold the value obtained in the control group. In COPD stage $\mathrm{B}$, the CRP/CIC index was slightly lower compared to COPD stage D. This was caused probably by the presence of higher CRP value in COPD stage D compared to B because the CIC values in the above-mentioned groups were comparable.

The dominant immune mechanism in COPD is the response associated with inflammatory nonspecific reactions. Similar results were presented in papers of other authors $[2,7,17]$. Consequently, systemic clinical signs of inflammation are observed (e.g. increased risk of cardiovascular disease, cachexia, skeletal muscle atrophy, osteoporosis, depression, and anaemia) $[11,18]$.

In our further studies, we attempted to characterise cellular components of inflammation among patients with obstructive lung diseases. An example of this is the NLR. The entire study group was characterised by a median NLR three times higher than that of the controls. This index was almost identical in the whole group of obstructive diseases as in the mild stage of COPD (5.4), while in the more advanced COPD stage it was slightly lower (4.75).

Other authors, Lee et al. [3], Halper-Stromberg et al. [19], and Sakuri et al. [20], showed that the NLR values were higher in COPD compared to the control and positively correlated with the severity of the disease. Our results differ in the most severe stage of the disease, and this may be related to the appearance of a specific response related to the chronicity of the disease. In general, nonspecific cellular responses predominate in mechanisms associated with COPD. However, in advanced, long-lasting COPD these mechanisms may become more specific.

Another explanation for differences of inflammatory pattern in different COPD stages may be the lack of symptoms of systemic inflammation in favour of local inflammatory reactions [16].

Obstructive diseases belong to the group of chronic diseases. The consequence of chronicity of the disease may be the dominance of immunological specific processes. Specific mechanisms require time and repeated antigenic stimulation. During stimulation, the antigen presentation takes place, and the Th lymphocytes are stimulated and differentiated into the Th1 and Th2 subtypes. Both antigens of microorganisms (exogenous and those that constitute the endogenous flora of the patient) and native antigenic forms, such as various proteins, haptens, etc., may be involved [21].

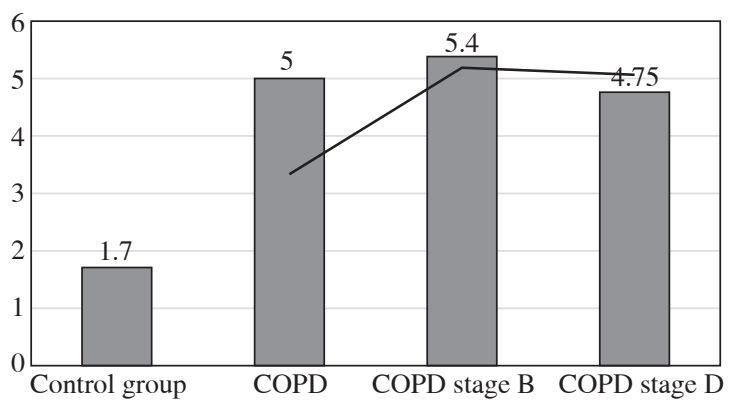

Fig. 2. Median values of neutrophil/lymphocyte ratio in the study group and control group

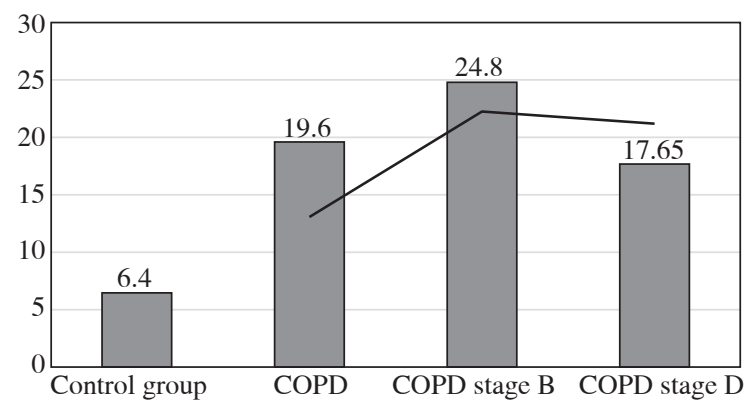

Fig. 3. Median values of platelet/lymphocyte ratio in the study group and control group

In the current literature, the usefulness of the PLR was assessed. Its predictive value of death in acute coronary syndromes and adverse events after angioplasty with stents covered with antimitotic medication was suggested. PLR may also reflect the severity of obstructive sleep apnoea and hypertension [22-25]. We have shown that the median value of PLR was 3.5-times higher in the entire study group (20.4) compared to the controls (6.4). This index is higher in mild forms of COPD (24.8), but in stage D it is slightly lower (17.65). The PLR may be evidence that the severity (chronic) of the disease is triggered by mechanisms related to the specific response.

\section{Conclusions}

The values of the analysed biochemical, immunological, and morphological parameters (with the exception of absolute lymphocyte number) were significantly higher in patients with obstructive diseases compared to healthy controls.

The NLR and PLR did not significantly differentiate subgroups B and D of patients with COPD; however, there was a tendency for slightly lower values in stage $\mathrm{D}$, which seems to be related to higher absolute lymphocyte number in chronic stages of the disease. 
CRP/CIC was slightly higher in COPD stage D compared to stage B, possibly due to higher CRP in group D. Based on our results, we suggest that the role of non-specific inflammatory mechanisms may increase in more advanced COPD stages (D) compared to less advanced stages (B).

The authors declare no conflict of interest.

\section{References}

1. Templeton AJ, McNamara MG, Šeruga B, et al. (2014): Prognostic role of neutrophil-to-lymphocyte ratio in solid tumors: a systematic review and meta-analysis. J Natl Cancer Inst 106; dju124.

2. Lenártová P, Kopčeková J, Gažarová M, et al. (2017): Biochemical parameters as monitoring markers of the inflammatory reaction by patients with chronic obstructive pulmonary disease. Rocz Panstw Zakl Hig 68: 185-190.

3. Lee H, Um SJ, Kim YS, et al. (2016): Association of the Neutrophil-to-Lymphocyte Ratio with Lung Function and Exacerbations in Patients with Chronic Obstructive Pulmonary Disease. PLoS One 11: e0156511.

4. Gołda R, Przybylski G, Dokładna W, et al. (2013): Analiza występowania atypowych białek w surowicy u chorych na raka płuc palących i niepalących papierosy. Przegl Lek 70: 784-786.

5. Gołda R, Przybylski G, Jóźwicki W, Wyszomirska M (2012): Krążące kompleksy immunologiczne, białko szoku cieplnego w surowicach osób z alergią palących tytoń - badania wstępne. Przegl Lek 69: 737-739.

6. Pilaczyńska-Cemel M, Przybylski G, Gołda R, Dąbrowska A (2017): Charakterystyka poziomów białka C-reaktywnego, krążących kompleksów immunologicznych u osób z przewlekłą chorobą obturacyjną płuc (POChP) palących i niepalących papierosy. Przegl Lek 74: 502-505.

7. Dahl M, Vestbo J, Lange P, et al. (2007): C-reactive protein as a predictor of prognosis in chronic obstructive pulmonary disease. Am J Respir Crit Care Med 175: 250-255.

8. Thomsen M, Dahl M, Lange P, et al. (2012): Inflammatory biomarkers and comorbidities in chronic obstructive pulmonary disease. Am J Respir Crit Care Med 186: 982-988.

9. Han YC, Yang TH, Kim DI, et al. (2013): Neutrophil to Lymphocyte Ratio Predicts Long-Term Clinical Outcomes in Patients with ST-Segment Elevation Myocardial Infarction Undergoing Primary Percutaneous Coronary Intervention. Korean Circ J 43: 93-99.

10. Yoon NB, Son C, Um SJ (2013): Role of the neutrophil-lymphocyte count ratio in the differential diagnosis between pulmonary tuberculosis and bacterial community-acquired pneumonia. Ann Lab Med 33: 105-110.

11. Wójcik E, Stasik Z, Rychlik U, et al. (2016): Wskaźniki NLR i PLR w ocenie rokowania chorych na niedrobnokomórkowego raka płuca. Diagn Lab 52: 13-20.

12. Górecka D, Jassem E, Pierzchała W, Śliwiński P (2012): Zalecenia Polskiego Towarzystwa Chorób Płuc dotyczące rozpoznawania i leczenia przewlekłej obturacyjnej choroby płuc (POChP). Pneumonol Alergol Pol 80: 220254.

13.Światowa Inicjatywa Zwalczania Przewlekłej Obturacyjnej Choroby Płuc (2016).

14. Global Initiative for Asthma.
15. Hasková V, Kaslik J, Riha I, et al. (1978): Simple method of circulating immune complex detection in human sera by polyethyleneglycol precipitation. Z Immun Forsch 154: 399-406.

16. Chorostowska-Wynimko J (2011): Płuca nie są samotną wyspą - współczesne spojrzenie na choroby układu oddechowego. Penumonol Alergol Pol 79: 165-166.

17. Batura-Gabryel H (2011): Biomarkery w POChP - czy są nam potrzebne? Pneumonol Alergol Pol 79: 144-150.

18. Wouters EF, Creutzberg EC, Schols AM (2002): Systemic effects in COPD. Chest 121 (5 Suppl): 127S-130S.

19. Halper-Stromber E, Yun JH, Parker MM, et al. (2018): Systemic Markers of Adaptive and Innate Immunity are Associated with COPD Severity and Spirometric Disease Progression. Am J Respir Cell Mol Biol 58: 500-509.

20. Sakuri K, Chubachi S, Irie H, et al. (2018): Clinical utility of blood neutrophil-lymphocyte ratio in Japanese COPD patients. BMC Pulm Med 18: 65.

21. Barnes PJ (2016): Inflammatory mechanisms in patients with chronic obstructive pulmonary disease. J Allergy Clin Immunol 138: 16-27.

22. Guzik B, Niewiara $€$, Sucheta M, et al. (2016): Wartość predykcyjna stosunku liczby neutrofilów do limfocytów oraz liczby trombocytów do limfocytów u pacjentów ze współistniejącym ostrym zespołem wieńcowym i migotaniem przedsionków. Ostry Dyżur 9: 81-87.

23.Rabe KF, Watz H (2017): Chronic obstructive pulmonary disease. Lancet 389: 1931-1940.

24. Song YJ, Kwon JH, Kim JY, et al. (2015): The platelet-to-lymphocyte ratio reflects the severity of obstructive sleep apnea syndrome and concurrent hypertension. Clin Hypertens 22: 1.

25.Zhou D, Fan Y, Wan Z, et al. (2016): Platelet-to-Lymphocyte Ratio Improves the Predictive Power of GRACE Risk Score for Long-Term Cardiovascular Events in Patients with Acute Coronary Syndrome. Cardiology 134: 39-46. 